\title{
THE IMPACT OF EASTERN UKRAINIAN ARMED CONFLICT ON TOURISM IN UKRAINE
}

\author{
Enikő SASS \\ Ferenc Rákóczi II Transcarpathian Hungarian College of Higher Education, Department of Geography \\ and Tourism, 6 Kossuth Street, 90202, Berehove, Transcarpathia, Ukraine, e-mail: seni1980918@gmail.com
}

\begin{abstract}
Citation: Sass, E. (2020). THE IMPACT OF EASTERN UKRAINIAN ARMED CONFLICT ON TOURISM IN UKRAINE. GeoJournal of Tourism and Geosites, 30(2spl), 880-888. https://doi.org/10.30892/gtg.302spl14-518
\end{abstract}

\begin{abstract}
This study deals with Ukraine, a European country that in the last years became the scene of sanguinary demonstrations, transition of power and military acts. The armed conflict that evolved in Ukraine in late 2013 and early 2014 spread like wildfire all over the world. International mass elucidated the theme on a daily basis. These events caused a mass of senseless fatalities, this problem is practically unresolved to date, and as a result, the country fell into a deep economic recession. This shook the country population's sense of security and immediately did away with inbound tourist traffic. This study shows the concrete or secondary influence of the Ukrainian "hybrid war" and the events that followed it on the country's tourism. This paper shows the changes that occurred in the field of tourism based on the available statistical data. I specifically compared the 2013 statistical data prior to the armed conflict with those of 2017 characterized by stagnation of the conflict intensity; in some cases I present even more recent data.
\end{abstract}

Key words: tourism, security, Ukraine, armed conflict, hybrid war

$$
* \quad * \quad * \quad * \quad * *
$$

\section{INTRODUCTION}

After officially breaking its ties with the Soviet Union in 1991 Ukraine became an independent state. After the deep economic recession following its declaration of independence the country's social and economic situation was characterized by numerous problems (Dancs, 2009). After the change of the regime, Ukraine's borders opened for the west. As a result, Ukraine's abyss-like economic, political, cultural, and social lagging behind its neighbouring countries became apparent. It took almost a decade for the country to start developing slowly (Dancs, 2009; Berghauer, 2012). One of the keys to solve economic problems in some territories of the country was seen in tourism. The discovery of the opportunity gave rise to the formation and development of tourist services based on attractive natural and cultural conditions to boost economy and overcome livelihood problems. Even so, tourism has not become the key sector in Ukraine due to the numerous problems the country is struggling with: political instability, negative country image, underutilization of tourist attractions, lack of prominence at the international level, low level of services, long border crossing, corruption, non-observation of ecological regulations, low level of public security, transport and other infrastructure, insufficient development of street lighting and sewage disposal, low qualification of the human resources, language barriers, etc. (Sass, 2008). The enumerated facts have not shown radical change since becoming independent, the problems still persist - as other researchers of tourism have also pointed out - (Riashchenko et al., 2015; Kolosinska et al., 2018), the country still bears the striking features of Eastern European and post-socialist states, as well as the problems of a newly established and assembled from pieces country (Sass, 2017). The above-mentioned situation was further aggravated by the $2014-$ "hybrid war" as the specialists also call it - armed conflict in eastern Ukraine, the "new" Ukrainian crisis.

\section{LITERATURE REVIEW}

Security is one of the fundamental human needs all over the world. After creating the conditions for existence, this is our most important need according to the accepted human norms (Maslow, 1943). Nowadays tourism as well is becoming more and more controlled and influenced by security considerations. Travellers consider it important that the chosen destination, the target country or area, the road leading there, as well as the means of travelling be secure. It is not surprising in the light of recent years' criminal chronicle. Although tourism security issue is not a new social challenge for tourism has always presupposed some kind of risk factor (Michalkó, 2004; Bujdosó and Györki, 2011), nowadays terrorist acts and armed conflicts have increased in frequency, thus it is an issue of utmost significance to be solved on a daily basis both in developed or former socialist and in countries of the so-called third world. Nowadays, communication means enable one to immediately send and receive news of this kind, they usually evoke fear, anxiety, indetermination not only among the local population but also among a much wider audience.

After the tragic terrorist actions of 9/11 a group of researchers began to study the problems of safety and security; moreover, these problems have become a special area of research and field study in tourism (Kővári and Zimányi, 2011, p. 60). Several articles have examined the impact of terrorism on tourism (Dávid et al., 2007; Varga and Bagdi, 2011; Gaydukevich, 2017) in the past 10-20 years.

Gaydukevich (2017) claims these events have an extremely negative impact both on the affected countries' economy and the tourist industry in the whole world. However, besides the terrorist attacks numerous other events can be mentioned that influence travellers' behaviour, tourism organizations' risks and expenses (Dávid et al., 2007). These include natural disasters that evolved suddenly (earthquake, flood, tsunami), various diseases, fresh attacks of known (measles) and not experienced until now new epidemics (zika, various types of SARS), climate change, and global pollution of the environment. This list should also include the subject matter of the present research -wars, civil wars, political, geopolitical conflicts whose impact on the tourism of various countries evoked the interest of many researchers (Currie et al., 2004; Harb, 2016; Pokharel et al., 2018). Determining and analysis of the impact exercised on tourism is impeded by the fact that it is influenced by numerous other factors (Dávid et al., 2007), thus one can draw parallels between the impacts the above-mentioned events exercise on tourism. However, in my opinion, each case is unique. The following factors make events unique: the country where the terrorist attack occurred, the political, geopolitical conflict or war lasting for years, and, perhaps, the spread of the latter within the country. The events presupposing security risks evoke an immediate reaction from the travellers because the majority of tourists on the territory decide to return home and that can cause a wave of cancelled reserved trips (Dávid et al., 2007). The achievement of minimal damage to the tourism industry depends on how quickly 
the country's leadership can restore, maintain and steadily ensure order, security in the country, how quickly they can regain people's and potential tourists' trust. This, however, is largely influenced by the country's natural and cultural conditions, the intensity of the tourist attractions, the quality and quantity of services rendered, infrastructural and technical environment, economic, social and political attitude to tourism, i.e. how attractive the country is for tourists, as well as how important the functioning of this branch is for the country.

Aubert (2011), however, claims that the increase in the number of terror attacks, incalculableness of the international political situation, intensification of international conflicts only temporarily decrease tourist traffic. Varga and Bagdi (2011) came to this conclusion as well after studying the influence of occurring attacks in various countries. Despite the fact that the above-mentioned events exercise a negative influence on the country's tourist traffic and, consequently, on the formation of its economic indices for a particular period of time, it is certain that this fact has to be dealt with from the point of view of tourism demand and supply as well. That is why my research aims at studying the impact of eastern Ukrainian war on the country's tourism.

\section{A SHORT INTRODUCTION INTO THE UKRAINIAN EVENTS}

Ukraine borders on seven countries (Figure 1), thus possessing a special geopolitical position between the western world and Russia. However, it could never entirely fulfil the historically and geopolitically ideal role of "the bridge" and gain true economic advantage out of it.

Ukraine's existence and development as an independent country has never been seamless. With its $603.700 \mathrm{~km}^{2}$ territory, $42.0 \mathrm{million}$ (2018) population (IMF, 2019) the country is a potential good market for any global economy. Since 1991 both West (the USA, Western Europe) and East (Russia) attempt to keep it under its control and by 2014 Ukraine has become a confrontation zone.

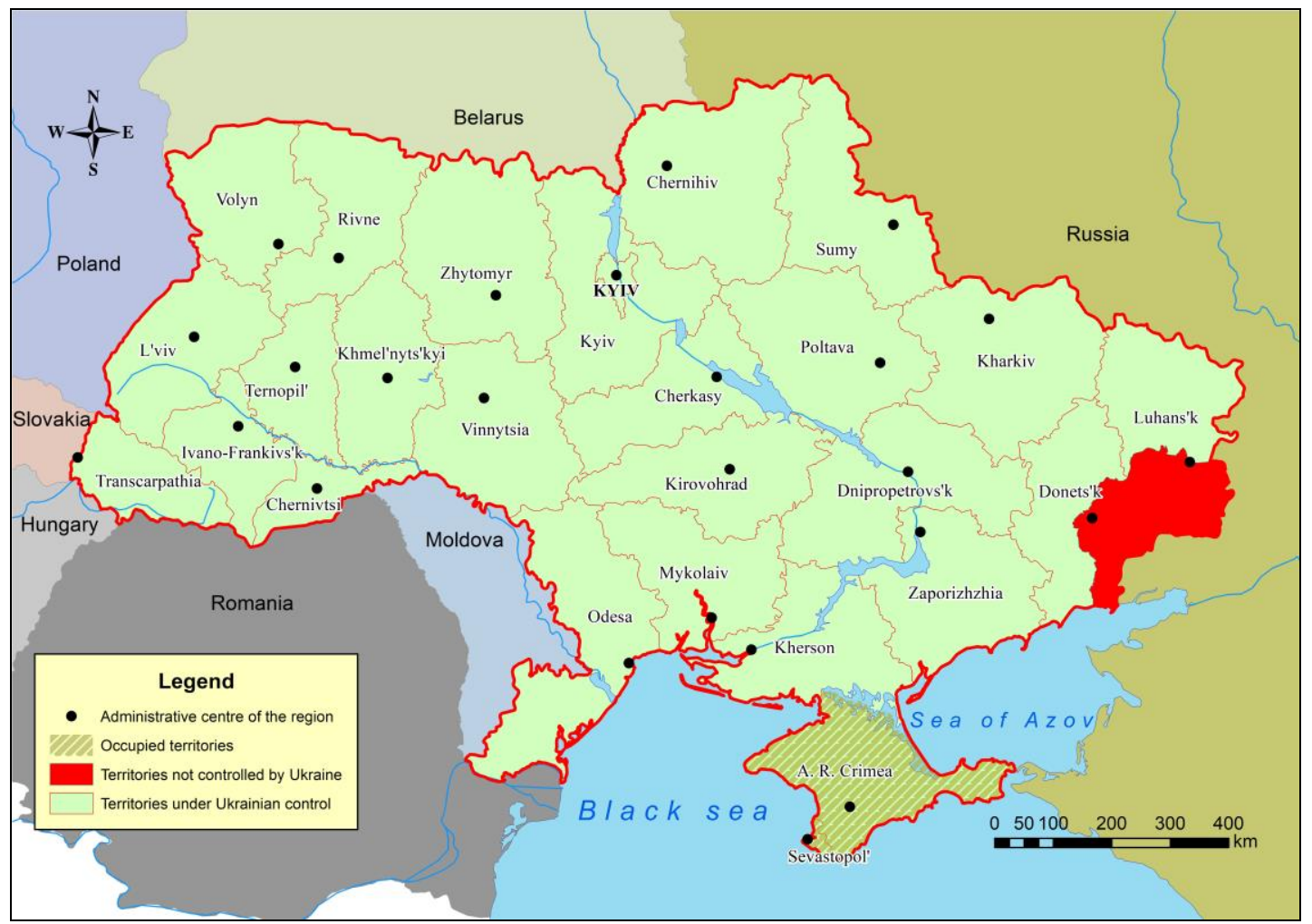

Figure 1. Ukraine's geographical position and the influence of hybrid war on the country's territorial unity (Source: author's own editing)

Opposition of the Yanukovych government to Eurointegration caused the November 2013 Independence Square demonstrations and led to the change of government. In March 2014 Russia annexed the Crimean Peninsula, in April Luhansk and Donetsk People's Republics were proclaimed (Csernicskó, 2016) (Figure 1) and as a result the Anti-Terrorist Operation (ATO) started to get back the territories causing fierce fights. Western Europe, with Germany acting as an intermediary, made numerous attempts to reconcile the parties. The peace-negotiations were held in Minsk (the most important agreement on ceasefire was concluded in 2015) and lately the talks were reopened in Paris at the end of 2019. Ceasefire in Western Ukraine has never been observed completely and the fight is going on ever since with lesser and/or greater intervals. Furthermore, currently COVID-19 pandemic reached the country. No one knows the extent the latest incidence will afflict the world and, in particular, Ukraine's population and economy. However, the impact of the events that have been going on ever since 2014 can be presented in concrete numbers. For instance, it is important from the point of view of the population that over 1 million people escaped from eastern Ukraine, and over 13 thousand people have died in the fighting so far. As to the economy, in 2014 the domestic demand in Ukraine dropped, weak foreign demand led to the decline of real GDP by $6.8 \%$, the national currency was quickly depreciated, thus aggravating the situation. In 2015 recession progressed further and as a result Ukraine's GDP decreased by $14.6 \%$ compared to the first half of the same year (Millennium Development Goals, 2015).

Side by side with the unresolved issues, since 2017 the Ukrainian government has adopted numerous laws, decrees (The Continuous Restriction of Language Rights in Ukraine, 2019) that restrict and infringe minorities' educational, language, etc. rights, thus causing tension on territories populated by the minorities, for instance in Transcarpathia. As a result, Ukraine fell into a political disagreement with all its neighbouring countries causing frequent extremist manifestations that keep the minority population in fear. Since the outbreak of the conflict there have been numerous cases when the situation in the country became critical (for example, annexation of the Crimean Autonomous Republic, Ilovaisk events, "Debaltsevo cauldron", etc.), however, none of them was considered reason enough by the then Prime Minister P. Poroshenko and the National Security Council to introduce the state of war. It happened in November 2018, as a result of a sea incident between Russia and Ukraine. At the time a state of war was announced in 10 regions for a month. 
In recent years events in Ukraine evoked the interest of many researchers who started analysing the situation in the country from various points of view. Some researchers pointed out the possible causes and solutions of problems, as well as revealed their consequences (Karácsonyi et al., 2014; Erőss et al., 2016; Tátrai et al., 2016; Smoor, 2017; Mykhnenko, 2020). Others studied the developmental problems and competitiveness of the tourism market in Ukraine (Riashchenko et al., 2015; Nezdoyminov and Shykina, 2016; Kolosinska et al., 2018). In response to the 2013-14 events in Ukraine numerous countries, including Hungary's Ministry of Foreign Affairs classified Ukraine from the point of view of travelling and stay into "II Enhanced security risk countries and territories" which is still valid (Figure 2).

All these factors do not improve the country's economic situation, and do nothing to develop tourism. Though Taleb Rifai (SecretaryGeneral, UNWTO) claims "Tourism is one of the most resilient and fastest-growing economic sectors but it is also very sensitive to risks, both actual and perceived." He also reminded that "misunderstanding often exaggerates and misrepresents real critical situations, thus causing serious challenges for the destinations concerned, while at the global level tourist demand remains strong" (Magyar Turisztikai Ügynökség, 2016, p. 1). Ukraine had to face the challenges as well and I will present these results here.

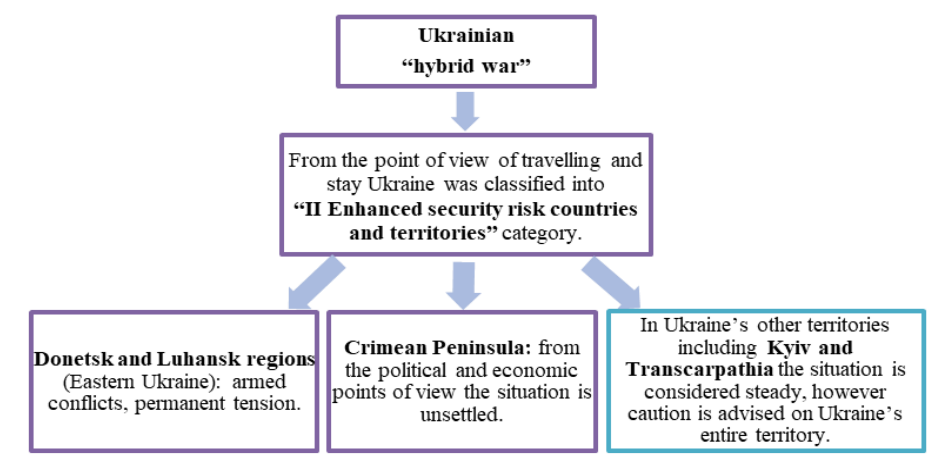

Figure 2. Ukraine's international listing from the point of view of travelling and stay

(Source: author's own editing based on Hungarian Consular Services, 2019)

\section{METHODOLOGY}

The 2014 Ukrainian hybrid war resulted in various political, social, and economic changes in the country that influenced its tourism industry. In this study I would like to demonstrate the relation between the changes occurring in the country's tourism industry influenced by the armed conflict on the basis of available statistical data. Taking this into account, the chosen research methods include processing international (UNWTO 2015, 2017, 2018a, 2018b, 2020; WTTC 2014, 2018) and home (State Statistics Service of Ukraine 2014, 2018a, 2018b, 2019a, 2019b) statistical data. For the statistical analysis I have chosen to compare the 2013 pre-conflict statistical data and the 2017 data when the conflict intensity was stagnating. Depending on the availability of data, in some cases 2018 data will also be published. However, more recent, i.e. 2019 statistical data on tourism are not yet available in Ukraine.

The primary aim of the study is to make a comparative analysis based on the statistical data on tourism in the chosen years, to elucidate the degree of negative or positive changes, as well as the cause-and-effect relationship. In the course of the analysis I studied, inter alia, the formation of Ukraine's tourist traffic, the economic indices of tourism, some of the main components of the tourism sector, the number of tourism organizations and collective accommodation facilities, as well as the country's tourist traffic.

\section{RESULTS DISCUSSIONS}

On a world scale, from the point of view of international tourism, 2017 set a record because the number of international tourist arrivals showed continuous over $4 \%$ increase for eight successive years. The global number of international tourist arrivals reached 1,326 million people, i.e. $7.0 \%$ ( 86 million international tourist arrivals) more than in 2016 (UNWTO, 2018a). In 2017 travelling and tourism as a branch of economy amounted to 10.4\% of the global GDP and 9.9\% (313 million jobs) of the total employment, thus it can be regarded as one of the largest and most dynamically developing branches of economy (WTTC, 2018). This fact is further substantiated by the increase of the 2018 and 2019 index-numbers. 2019 was the tenth consecutive year of sustained growth since 2009 (UNWTO, 2020, p.3). As far as 2017 is more significant for the present research, I will not analyse these data in detail.

In 2017671.1 million people arrived in Europe amounting to half (50.7\%) of the world's international tourist arrivals. 19.8\% (133.0 million people) travelled to Central and Eastern Europe. This means a 4.5\% increase compared to the previous year. In 2017 the above-mentioned European region had a $10.1 \%$ share in the world's tourist arrivals. Statistically, Ukraine belongs to Central and Eastern Europe territory. In 2017 the country totalled $1.1 \%$ of the world's international tourist arrivals, $2.1 \%$ of the European ones, and $10.7 \%$ share in East-Central Europe (UNWTO, 2018b). From the point of view of inbound tourism, these rates mean a huge decline for Ukraine compared to late 2000s and early 2010s.

According to Ukraine's State Customs Service Administration data published by State Statistics Service of Ukraine, 40667055 people were registered at border crossing points in 2017. They included 26437413 Ukrainian citizens travelling abroad and 14229642 foreigners entering the country (Figure 3). These data include both inbound and outbound tourist traffic. Although we know that the Ukrainian statistical service data series are not fully compatible with the European data series (Gyuricza, 2017), in the "International tourist arrivals" table UNWTO shows Ukraine's frontier traffic data. However, frontier traffic data also include one-day visitors (www.ukrstat.gov.ua), who do not necessarily cross the border for tourist reasons. Some of them cultivate family and friendly relations with people living on both sides of the border or travel for shopping. Others (and probably the majority) look for business and subsistence opportunities in the neighbouring countries. At the Hungarian-, Slovak-, Polish-Ukrainian borders "contraband tourism" is still flourishing (Berghauer, 2012; Gyuricza, 2017). A new issue is the obligatory clearance of foreign vehicles brought to Ukraine out of the country every 5 days, thus significantly increasing the number of border crossings.

Figure 3 shows a continuous, dynamic, annual average 19.2\% growth of international tourist arrivals from 2000 to 2008 in Ukraine. As a result of the global economic recession it was followed by a sudden $18.2 \%$ fallback by 2009 . This crisis could be felt all over the world. It took four years for the Ukrainian inbound tourism to come close to the 2008 level, i.e. 24.7 million tourists were registered by 2013 . In the course of the four years the previous growing demand period was followed by a slow, average $4.4 \%$ increasing tendency. In 2014 came an unexpected and drastic downturn: the inbound traffic dropped by $48.5 \%$, followed by a further $2.2 \%$ decrease in 2015 , thus coming close to the 2003 low level of inbound tourism. Although there is an annual average 7\% increase since 2015, the 2008 record of 25.4 million inbound 
tourists is still a long way to go. For the sake of accurate interpretation of data, it should be mentioned that since 2014 State Statistics Service of Ukraine does not publish data on the Crimean Autonomous Republic, the city of Sevastopol, as well as part of Donetsk and Luhansk regions (www.ukrstat.gov.ua). The substantial decline in the number of inbound tourists is explained, firstly, by the loss of tourist traffic to the above-mentioned territories, secondly, tourists stayed away due to fear of the warlike situation.

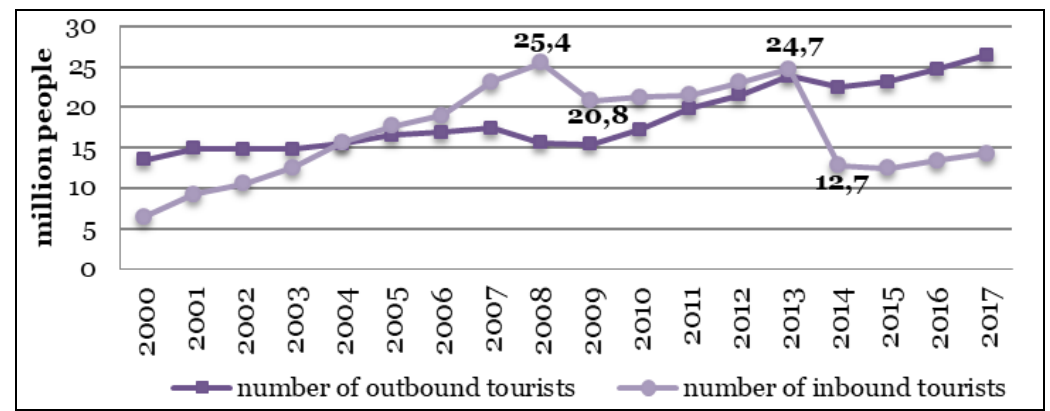

Figure 3. The number of outbound and inbound people in Ukraine in 2000-2017 (Source: author's own editing based on www.ukrstat. gov.ua)

The number of Ukrainian outbound tourists (Figure 3) shows a slow increase in tourism (annual 3.8\% in average) between 2000-2007. In the period 2007-2009 it fell back by 11.7\%, while nowadays - except 2014 - it is followed by another annual average 9\% growth.

Compared to 2013, in 2017 the inbound traffic dropped by $42.3 \%$, while the outbound traffic increased by $11.3 \%$, i.e. the number of outbound tourists is much higher than the number of inbound ones.

The change of structure in the sphere of tourist flow can be attributed to the war situation in the country. Kolosinska et al. (2018, p.250) also states that the political and economic instability that exists in Ukraine hinders the development of internal and inbound tourist flows. The outbreak of the Russian-Ukrainian conflict_caused recession in Ukraine's economy and, as a consequence, decrease in the population's standard of living as well. The difficult economic situation and fear of the war made the working population look for employment abroad. However, statistics cannot keep a proper record of the labour turnover due to its significant illegal character (Tátrai et al., 2018), and it is highly probable that a great part of these people crossed the border with a tourist visa (before 2017), were registered as tourists at border crossing points. Outbound traffic was further increased by the loss of the favourite part of the country for inland tourism the Crimean Peninsula, as well as by visa-free border crossing between Ukraine and the European Union since 11 June 2017.

In 2017 the majority of people travelled from Ukraine to neighbouring countries; travellers to Poland, Russia and Hungary amounted to more than a half (66.1\%) of the outbound traffic. The 10 favourite destinations amount to $92.7 \%$ of travelling abroad. In 2013 the destination countries were the same. The only changes were in their order and their turnover share (Table 1). Compared to 2013, in 2017 the greatest fall in demand was for Russia, Moldova and Belarus, a smaller fall for Germany, the rest of the top 10 countries increased interest towards their countries. The main reason for the significant decrease in the number of travellers to Russia ( -1.8 million) is the Russian-Ukrainian conflict and security risk, however, due to visiting relatives along the Russian-Ukrainian border, as well as guest work that has been going on for decades, the decrease is only $28.7 \%$. However, the number of Ukrainian tourists travelling to Egypt and Turkey doubled. It happened despite the fact that in recent years terrorist attacks in Turkey $(2016,2017)$ and Egypt $(2014,2015)$ became more frequent.

Table 1. The number of outbound people and its change grouped into countries (TOP 10) (Data source: author's own editing based on www.ukrstat.gov.ua)

\begin{tabular}{|c|c|c|c|c|c|}
\hline \multicolumn{2}{|c|}{ Rank } & Target countries & \multicolumn{2}{c|}{ The number of outbound people } & Change in the number of outbound people (\%) \\
\hline $\mathbf{1 7}$ & $\mathbf{1 3}$ & & $\mathbf{2 0 1 7}$ & $\mathbf{2 0 1 3}$ & $\mathbf{1 7 / 1 3}$ \\
\hline 1. & 1. & Poland & $9,990,978$ & $6,991,778$ & 42.9 \\
\hline 2. & 2. & Russia & $4,376,423$ & $6,140,406$ & $\mathbf{- 2 8 . 7}$ \\
\hline 3. & 4. & Hungary & $3,118,758$ & $1,900,469$ & 64.1 \\
\hline 4. & 3. & Moldova & $1,680,353$ & $2,395,258$ & $\mathbf{- 2 9 . 8}$ \\
\hline 5. & 5. & Belarus & $1,186,466$ & $1,738,907$ & $\mathbf{- 3 1 . 8}$ \\
\hline 6. & 7. & Turkey & $1,185,051$ & 573,840 & 106.5 \\
\hline 7. & 6. & Romania & $1,045,424$ & 791,845 & 32.0 \\
\hline 8. & 8. & Slovakia & 854,657 & 571,266 & 49.6 \\
\hline 9. & 10. & Egypt & 733,597 & 336,173 & 118.2 \\
\hline 10. & 9. & Germany & 344,150 & 376,316 & -8.5 \\
\hline \multicolumn{2}{|c|}{ Total } & & $\mathbf{2 4 , 5 1 5 , 8 5 7}$ & $\mathbf{2 1 , 8 1 6 , 2 5 8}$ & \\
\hline
\end{tabular}

Table 2. The number of inbound people and its change- grouped into countries (TOP 10) (Data source: author's own editing based on www.ukrstat.gov.ua)

\begin{tabular}{|c|c|c|c|c|c|}
\hline \multicolumn{2}{|c|}{ Rank } & \multirow{2}{*}{ Countries of dispatch } & \multicolumn{2}{|c|}{ The number of inbound people } & \multirow{2}{*}{$\begin{array}{c}\text { Change in the number of inbound people (\%) } \\
17 / 13\end{array}$} \\
\hline '17 & '13 & & 2017 & 2013 & \\
\hline 1. & 2. & Moldova & $4,435,664$ & $5,417,966$ & -18.1 \\
\hline 2. & 3. & Belarus & $2,727,645$ & $3,353,652$ & -18.7 \\
\hline 3. & 1. & Russia & $1,464,764$ & $10,284,782$ & -85.8 \\
\hline 4. & 4. & Poland & $1,144,249$ & $1,259,209$ & -9.1 \\
\hline 5. & 6. & Hungary & $1,058,970$ & 771,038 & 37.3 \\
\hline 6. & 5. & Romania & 791,116 & 877,234 & -9.8 \\
\hline 7. & 7. & Slovakia & 366,249 & 424,306 & -13.7 \\
\hline 8. & 10. & Turkey & 270,695 & 151,706 & 78.4 \\
\hline 9. & 12. & Israel & 261,486 & 120,913 & 116.3 \\
\hline 10. & 8. & Germany & 209,447 & 253,318 & -17.3 \\
\hline \multicolumn{2}{|c|}{ Total } & & $12,730,285$ & $22,914,124$ & \\
\hline
\end{tabular}


Like in many European countries, the most powerful is the tourist flow between the neighbouring states. Moreover, the neighbouring countries provide tourist traffic of same day visitors, particularly transit tourists (Riashchenko et al., 2015). 2017 was no exception - the majority of inbound tourists came from countries Ukraine borders on (Table 2) because the seven neighbouring states comprise $84.3 \%$ of the inbound traffic. Compared to 2013, in 2017 the top 10 countries of dispatch were characterized by a drop in the number of travellers. The greatest drop (-85.8\%), which is not surprising, was in the case of Russia, amounting to 8.8 million people.

The non-arrival rate of Russian tourists in Ukraine is much higher than the non-arrival rate of Ukrainian tourists in Russia. As it has already been mentioned, in 2014 Crimea disappeared from Ukrainian statistics, however it appeared in the Russian one. Consequently, the Russians were registered as domestic tourists within Russia, not as Ukraine's foreign ones. In the pre-annexation years three fourths of the approximately 2 million foreign tourists were Russians (Gyuricza, 2017).

\section{Economic indices of tourism in Ukraine}

The fact that Ukraine lost its attractiveness as a result of another recent Ukrainian crisis can be best illustrated by the following information - while in 1995 it was 32nd in the world tourist destination rankings, by 2005 it reached the distinguished 13th position (UNWTO, 2007; Sass, 2008), while in 2013 it was 14th (UNWTO, 2015). However, by 2017 it fell back to the 27th place (Table 3) and this tendency develops further in 2018 when the country is positioned as 30th (UNWTO, 2020).

Table 3. The correlation of international tourist arrivals and tourism receipts

in Ukraine and other countries $(2013 ; 2017)$ (Data source: author's editing based on UNWTO, 2015, 2017, 2020)

\begin{tabular}{|c|c|c|c|c|c|c|}
\hline & & Country & International tourist arrivals ( $\mathrm{mn}$ people) & & & International tourism receipts (USD bn) \\
\hline \multirow{5}{*}{ 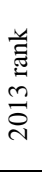 } & 9. & Russia & 28.4 & \multirow{5}{*}{ 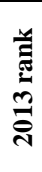 } & 27. & 12.0 \\
\hline & 13. & Austria & 24.8 & & 14. & 20.2 \\
\hline & 14. & Ukraine & 24.7 & & $*$ & 5.1 \\
\hline & 15. & Mexico & 24.2 & & 22. & 13.9 \\
\hline & 26. & Hungary & 10.7 & & 45. & 5.4 \\
\hline \multirow{5}{*}{ 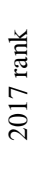 } & 24. & Hungary & 15.8 & \multirow{5}{*}{ 范 } & 45. & 6.2 \\
\hline & 26. & India & 15.5 & & 13. & 27.3 \\
\hline & 27. & Ukraine & 14.4 & & $*$ & 1.3 \\
\hline & 28. & Singapore & 13.9 & & 19. & 19.7 \\
\hline & 39. & Bulgaria & 8.9 & & $*$ & 4.0 \\
\hline
\end{tabular}

(* - the country is not in the first 50 ranking list in tourism receipts)

In accord with the tourist destination rank, i.e. the number of international tourist arrivals, there was a growing interest towards Ukraine; more and more people visited this once closed and therefore unknown destination. However, behind the high international tourist arrivals there are low international tourism receipts, e.g. in 2013 Ukraine being 14th on the world ranking list (24.7 million inbound people) could not surpass Hungary in revenue that was 25th (10.7 million inbound people. By 2017 the situation deteriorated even more for Ukraine fell back to the 27th place and made three times less profit than Bulgaria that was 39th. What concerns immediate competitors in the rank, it cannot compete with them at all (Table 3).

Table 4 shows the extent tourism contributed to the development of Ukraine's economy, creation of jobs before and "after" the conflict. Therefore, the gross added value of branches of tourism was 3.8 billion USD (2013: world average was 18.0 billion USD) in 2013 amounting to 2.3\% (2013: European average was 3.1\%, world average was 2.9\%) direct contribution to GDP, while entire contribution was $8.6 \%$ (2013: European average was 8.7\%, world average was 9.5\%) (WTTC, 2014). The values of direct and indirect contributions in dollars are far below average indices of other countries of the world and Europe. GDP share of tourism in per cent is closer to other countries' average, however it is achieved from low gross domestic product. In 2013 Ukraine's GDP was 179.57 billion USD, by 2017 it dropped to 112.13 billion USD (Statista, 2020). The 2017 economic indices of tourism are even worse for both direct and indirect contribution indices dropped more than a half compared to 2013 (Table 4). However, compared to the 2016 values - except employment - a minimal increase could be observed in 2017.

In 2013 the number of people employed in tourism was 416 thousand, thus tourism directly generated $2.0 \%$ of jobs. Summarizing the direct and indirect impacts, it amounted to $7.7 \%$ of national economy employment (WTTC, 2014). These proportions fell back to $1.4 \%$ and $5.1 \%$ by 2017 (WTTC, 2018). Moreover, visitor export and capital investment decreased by more than a half in the period under analysis.

Table 4. The contribution of tourism into Ukrainian economy $(2013 ; 2017)$ (Data source: author's own editing based on WTTC, 2014, 2018)

\begin{tabular}{|c|c|c|c|c|}
\hline & 2013 & 2017 & 2013 & 2017 \\
\hline GDP: direct contribution & 3.8 (USD bn) & 1.5 (USD bn) & $2.3 \%$ of total GDP & $1.5 \%$ of total GDP \\
\hline GDP: total contribution & 14.3 (USD bn) & 5.5 (USD bn) & $8.6 \%$ of GDP & $5.7 \%$ of GDP \\
\hline Employment: direct contribution & 416000 workplaces & 228000 workplaces & $2.0 \%$ of total employment & $1.4 \%$ of total employment \\
\hline Employment: total contribution & 1570000 workplaces & 855800 workplaces & $7.7 \%$ of total employment & $5.1 \%$ of total employment \\
\hline Visitor exports & 5.8 (USD bn) & 1.6 (USD bn) & $7.1 \%$ of total exports & $3.3 \%$ of total exports \\
\hline Investment & 0.7 (USD bn) & 0.3 (USD bn) & $2.2 \%$ of total investment & $1.9 \%$ of total investment \\
\hline
\end{tabular}

\section{Change in Ukraine's tourism sector in the period under analysis}

In addition to casualties, the biggest victims of terrorist attacks, military conflicts, civil wars, various coups d'état are economy actors, viz., tourism market actors, e.g. airline companies, tour operator and mediator sector, as well as hotels (Aubert, 2011), thus the study of the above-mentioned research areas is indispensable from the point of view of analysing Ukraine's tourism trend.

Transport is part of basic infrastructure together with public utilities and communications. As far as tourism includes land, air and water transport use (passenger planes, luxury ocean liners, tour buses, trains, private or rented cars) (Varga and Bagdi, 2011), the decrease in the number of tourists can cause or intensify the decline of traffic of the above-mentioned means of transport.

State Statistics Service of Ukraine (2019b) data testify to the fact that railway and road traffic dominate in Ukraine's passenger traffic. Having analysed passenger traffic from the point of view of various means of transport, we can see that the traffic of bus, sea and river means showed a decreasing tendency before the conflict with Russia (before 2014), while air traffic was on the increase. Following the annexation of 
the Crimean Autonomous Republic maritime passenger traffic was completely discontinued. Significant decrease of bus passenger traffic continued, while during the crisis (2014 and 2015) railway passenger traffic decreased minimally (by 8.8\%) (Figure 4a). Even a low percent change of those means of travelling (in this case trains and buses) that play a decisive role in the population's everyday conveyance means several million passengers. River passenger traffic reached the lowest point in 2013, but it showed growth by 2014 (Figure 4b).

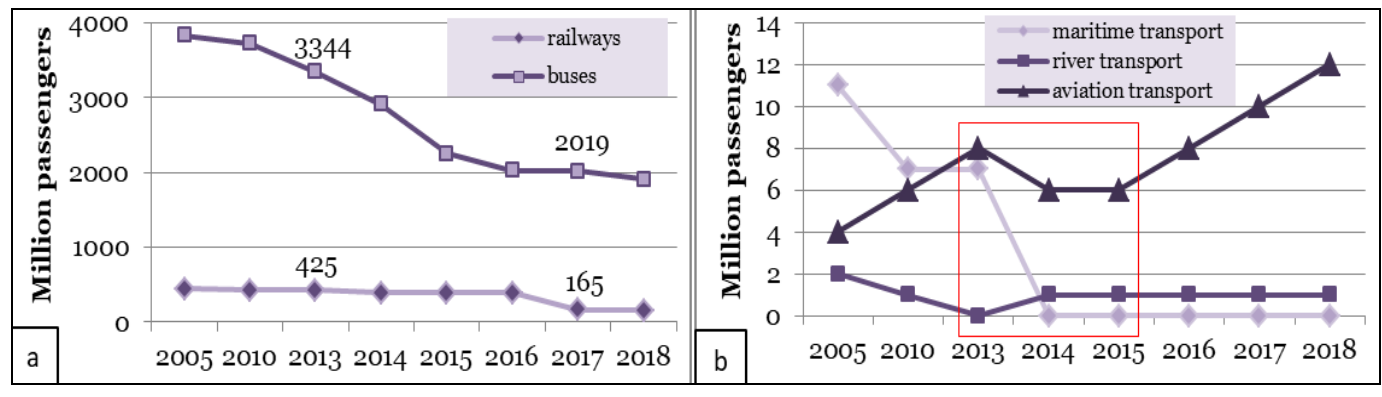

Figure 4. Change in the number of passengers per means of transport (Source: State Statistics Service of Ukraine, 2019b)

The most interesting changes in passenger traffic can be observed in air passenger transport. In 2018 Ukrainian passengers preferred travelling by plane showing high growth rates $(25.8 \%)$ for the third year in a row, followed by the recovery of the market after the decline of air traffic in 2014 and 2015 (the two years showed a total decline of 22.8\%). By 2016 airline passenger traffic regained the volume of the years before 2014. The number of enplaned passengers in 2017 increased by $27.5 \%$ in comparison to 2016 . The dynamic increase in the number of airline passengers can be attributed to the development of international airline traffic (AASISTS, 2018).

Analysing the composition of airline passenger traffic, we can see that the proportion of international tourists is much higher than that of inland ones (Figure 5). While in 2013 the proportion amounted to $14.9 \%$, by 2018 it did not reach $10.0 \%$.

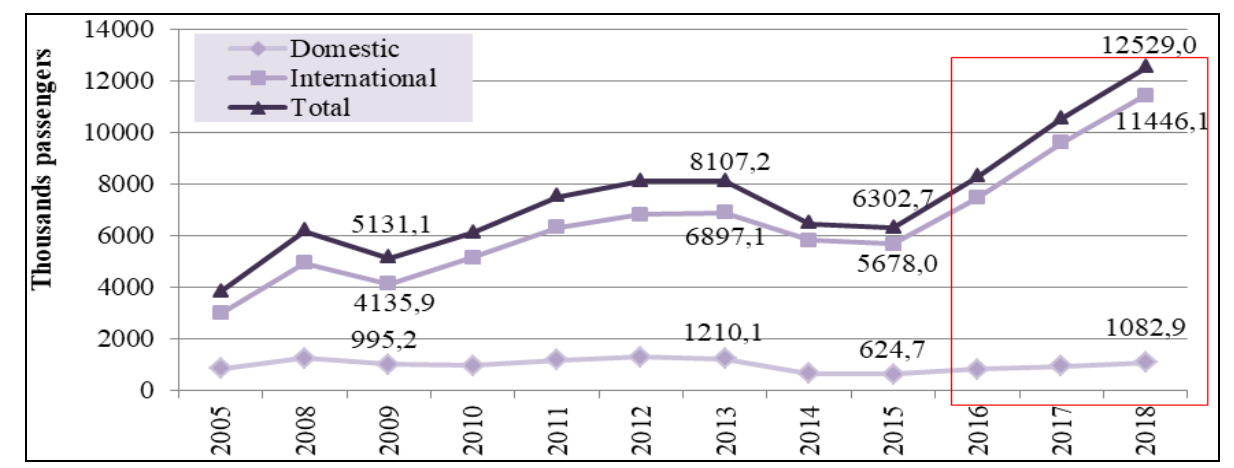

Figure 5. Change in the number of passengers in Ukraine (thousand) (2005-2018) (Source: State Statistics Service of Ukraine, 2019b)

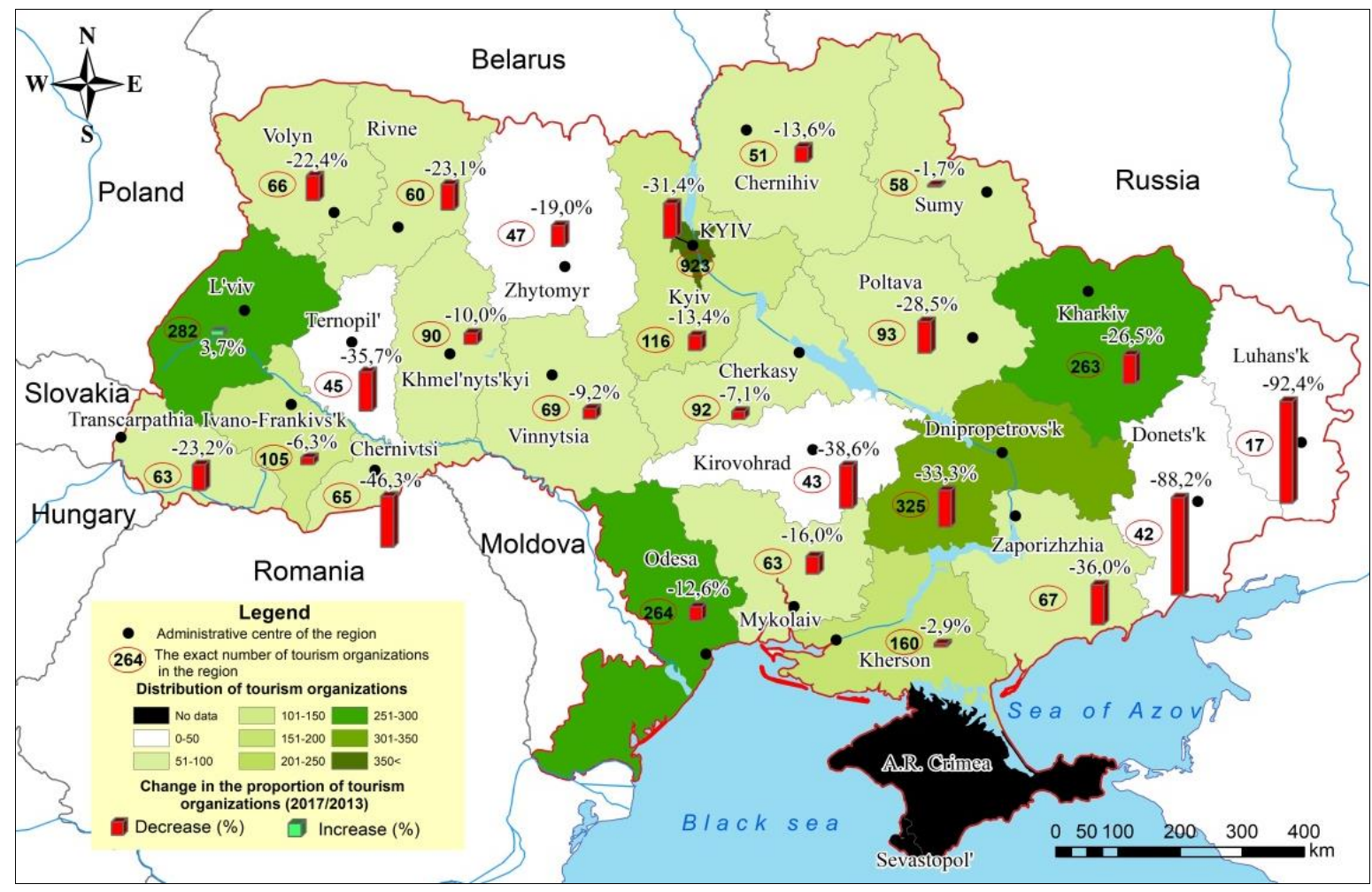

Figure 6. Distribution of entities of tourist activity in Ukraine per administrative unit

(2017; 2017/2013) (Source: author's editing based on State Statistics Service of Ukraine 2014, 2018a) 
In 2013 domestic air services provided 130,000 seats. Since 2013 three airlines (Aerosvit, UTair-Ukraine, and Wizz Air Ukraine) discontinued their domestic air operations because of the 25\% volume shrinkage from 2013 to 2014 (AASISTS, 2018). As a result of the conflict between Russia and Ukraine, flights to separatist territories (Donetsk, Luhansk and Simferopol) were cancelled and operating licence was withdrawn from some airports.

In 2013 there were 5711 tourism organizations (mainly tour operators and travel agents) in Ukraine. Their number decreased by $39.3 \%$ (3469 units) by 2017. However, by 2018 a 23.8\% (4293 units) increase was registered (State Statistics Service of Ukraine, 2019a).

By 2017 the greatest setback was registered in the eastern parts of the country (Donetsk $(-88.2 \%)$ and Luhansk (-92.4\%) regions) - the zone of military actions. Surprisingly, the list was continued by a western-Ukrainian region (Chernivtsi (-46.3\%)). The only region where the number of tourism organizations grew was Lviv (+3.7\%) (Figure 6). In 2017 over half (59.3\%) of tourist companies in Ukraine were situated in five administrative units: Kyiv city (923), Dnipropetrovsk (325), Lviv (282), Odesa (264), Kharkiv regions (263) (State Statistics Service of Ukraine 2014, 2018a).

Tourism is quite a sensitive industrial sector directed mainly at peaceful territories (Aubert, 2011), or rather the population of peaceful territories who are its active participants. Thus, the results of this study testify to the fact that the hybrid war in Ukraine brought about an approximately $41.5 \%$ decline in the number of tourists served by tourism organizations in the country in the period from 2013 to 2015 . As a result, numerous tourist companies went bankrupt or stopped functioning, i.e. fell victim to the eastern Ukrainian conflict, just like other economic entities. With the decrease in the intensity of fighting and its stagnation, tourism slump started to ease and in 2016 the number of tourists served by tourism organizations grew. If I compare the data to the 2015 slump, we can see that three successive years were characterized by traffic increase and the increase from 2017 to 2018 was most outstanding. Owing to this process, the 2018 data exceeded the 2013 data (Table 5).

Table 5. Tourists served by tour operators and travel agents (2012-2018) (Data source: www.ukrstat.gov.ua)

\begin{tabular}{|c|c|c|c|c|c|c|c|}
\hline year & 2012 & 2013 & $2014^{*}$ & $2015^{*}$ & $2016^{*}$ & $2017^{*}$ & $2018^{*}$ \\
\hline the number of tourists & 3000696 & 3454316 & 2425089 & 2019576 & 2549606 & 2806426 & 4557447 \\
\hline
\end{tabular}

occupied territories in the Donetsk and Luhansk regions)

Statistical data show that in 2013 there were 6411 collective accommodation facilities in Ukraine. In Ukrainian statistics these facilities are called "collective accommodation" and include hotels and similar accommodation (hotels, motels, hostels, camping, agrohotels, tourist centres, etc.) as well as special accommodation (sanatoria, children's treatment-and-prophylactic spas, guesthouses, medical and recreational resorts, etc.) (State Statistics Service of Ukraine, 2018b). By 2017 their number declined as well (-35.8\%). The greatest decline after the eastern Donetsk (-73.6\%) and Luhansk (-72.4\%) regions was in Kherson (-38.0\%), Kirovohrad (-37.8\%) and Chernihiv (-36.4\%) regions. The number of collective accommodation facilities grew in 4 regions only in this period, with the greatest increase (approximately $21.8 \%$ ) in western Ukrainian Ivano-Frankivsk region. Taking into account the number of collective accommodation facilities in 2017, the top administrative units in the country were as follows: seaside (1. Odesa (529 accommodation facilities), 2. Zaporizhia (374), 5. Mykolaiv (271) and western Ukrainian (3. Lviv (337), 4. Ivano-Frankivsk (274), 6. Transcarpathian (250) regions (Figure 7).

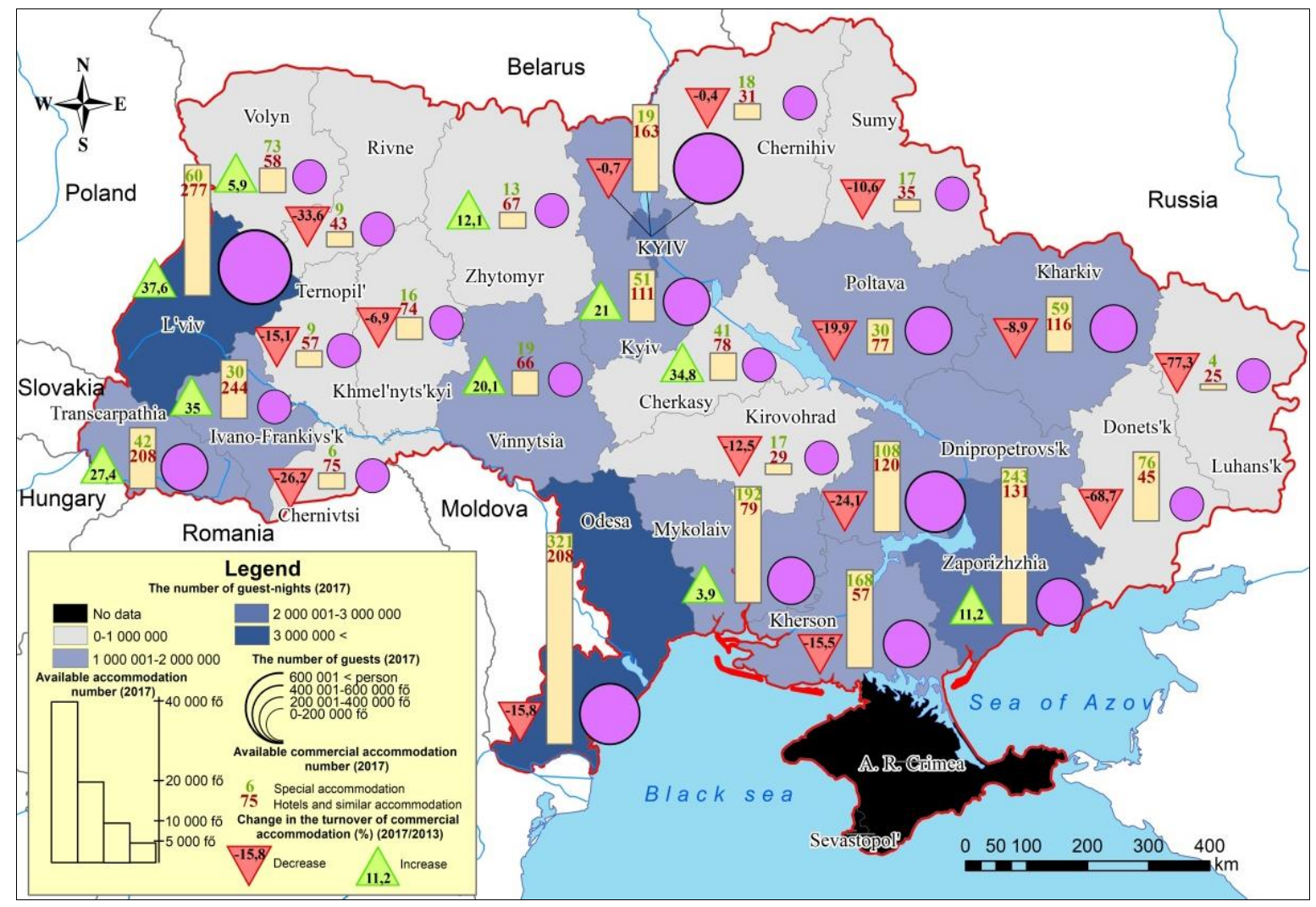

Figure 7. The number of collective accommodation facilities and tourism receipts (Source: author's edition based on State Statistics Service of Ukraine, 2014, 2018a)

In 2017 the country's collective accommodation facilities were concentrated in particular territories. Only 8 regions had over 200 units amounting to over half $(60.5 \%)$ of collective accommodation facilities. In 2013 the situation was similar. The Crimean Autonomous 
Republic with its 1225 accommodation facilities was by far the first. 11 administrative units had over 200 facilities amounting to $73.9 \%$ of collective accommodation facilities.

In 2013 collective accommodation facilities had over half a million (586643) bedspaces, however, by 2017 their number fell by 38.8\% (359034). In 2017 mainly the seaside regions had outstanding capacity - they were top five in the list with the exception of 3rd place Lviv region. 1. Odesa 2. Zaporizhia 4. Mykolaiv 5. Kherson (Figure 7). In the number of bedspaces, administrative units were mainly characterized by a declining tendency. However, in four regions growing capacity could be observed. The most significant increase was in Ivano-Frankivsk $(+24.9 \%)$ and Zaporizhia $(+10.4 \%)$ regions. Similarly to the number of collective accommodation facilities, the number of bedspaces in 2013 was by far the greatest in the Crimean Autonomous Republic. Moreover, it is worth mentioning that Donetsk region, part of which is now declared anti-terrorism operation territory, was 3rd in 2013 both in the number of collective accommodation facilities (13th in 2017) and in the capacity (8th in 2017).

\section{CONCLUSION}

This study gives insight into the changes in the tourism industry of the country where war has been going on for several years. The suggested statistical data testify to the fact that Ukraine's tourist traffic underwent a structural change which is closely related to the Eastern Ukrainian conflict that started in 2014. The 2014 events made a huge detrimental impact on the inbound tourism, unlike the outbound one where the damage caused was minor. As a result, after 10 years the number of outbound people exceeded the number of inbound ones, and this tendency still remains unchanged.

At the very start of the research it became clear that it is not worth comparing Ukraine's tourism to any other country's tou rism because both prior to the eastern Ukrainian conflict and in the period of its stagnation Ukraine cannot compete with its competitors either in the achieved international tourist arrivals rank or in the level of tourism receipts.

Nevertheless, as a result of the eastern Ukrainian armed conflict and annexation of the Crimean Peninsula, the economic changes in the country and in the tourism industry in particular had a comparable output as in any other country in a similar situation. The events caused a significant decline in each and every aspect of tourism (international tourist arrivals, tourism organizations, the number and traffic of collective accommodation facilities, etc.). However, the decrease in the intensity of fighting, its stagnation brought back people's sense of security, though not to the extent of 2013, but people started travelling both within the country and abroad.

Powerful recession of tourism and economy was mainly observed in 2014 and 2015. Though the conflict still persists and the problem has not been solved yet, the data testify to the fact that the decline did not last long. The actors of the tourism sector try to return to the market as soon as possible to serve the new clientele. After 2014 and 2015, in 2016 and 2017 the majority of statistical indices under analysis started growing slowly, though they exceeded the 2013 values in few cases (e.g. air passenger traffic, the number of tourists served by tourism organizations).

Although the country's tourist traffic has declined significantly in recent years, caused mainly by the exclusion of the tourist traffic on the territories that are now not controlled by the state (the Crimean Autonomous Republic, Sevastopol, part of Donetsk and Luhansk regions), tourism did not cease to exist in the country, it only decreased in amount and changed direction. The data (collective accommodation facilities) testify to the fact that the traffic took the direction towards safer territories and followed a north-western tendency. Currently, tourists show a growing interest towards central, western and seaside parts of the country.

In spite of the fact that in Ukraine neither the population's, nor the inbound tourists' lives are in danger, the judgement of the country's tourism security has been unfavourable for 7 years already. This international judgement will apparently not change until the country's unity is restored, i.e. the Crimean Peninsula and the Eastern Ukrainian conflicts are settled.

\section{REFERENCES}

Aubert, A. (2011). Turizmus trendek és térszerkezet Magyarországon [Tourism Trends and Configuration in Hungary]. Publikon Kiadó, Pécs, p. 143.

Berghauer, S. (2012). A turizmus, mint kitörési pont Kárpátalján (?) (Értékek, remények, lehetőségek Ukrajna legnyugatibb megyéjében). PhD értekezés. [Tourism as a Breakout Point in Transcarpathia (Values, hopes, opportunities in Ukraine's westernmost region). PhD thesis]. Pécsi T udományegyetem Természettudományi Kar, Földtudományok Doktori Iskola, Pécs, p. 213.

Bujdosó, Z. \& Györki, M. (2011). A biztonság szerepe a turizmusfejlesztésben [The Role of Security in Developing Tourism]. Acta Carolus Robertus 1. évf. 2. sz., 45-56.

Currie, D., Fellow, F., Skare, M. \& Loncar, J. (2004). The Impact of War on Tourism: the Case of Croatia, Conference on Tourism Economics, Palma de Mallorca.

Csernicskó, I. (2016). Nyelvpolitika a háborús Ukrajnában [Language Policy in Wartime Ukraine]. Autdor-Shark, Ungvár, p. 140

Dancs, L. (2009). Ukrajna társadalmi-gazdasági helyzete [Ukraine's Social and Economic Situation]. In: Baranyi, B. (ed.). Kárpátalja [Transcarpathia]. MTA Regionális Kutatások Központja, p. 25-64, Dialóg Campus Kiadó, Pécs-Budapest.

Dávid, L., Molnár, F., Bujdosó, Z. \& Dereskey, A. (2007). Biztonság, terrorizmus, turizmus [Security, Terrorism, Tourism]. GAZDÁLKODÁS: Scientific Journal on Agricultural Economics 51. évf. 20., 160-166.

Erőss, Á., Kovály, K. \& Tátrai, P. (2016). Effects of the Ukrainian crisis in Transcarpathia: the Hungarian perspective. Warsaw: Centre of Migration Research (Ośrodek Badań nad Migracjami), CMR Working papers, p. 92.

Gaydukevich, L.M. (2017). Security Problems in International Tourism. Journal of the Belarusian State University. International Relations, BSU, 1, 28-35, Belarusian State University, Minsk.

Gyuricza, L. (2017). A turizmus és biztonság kérdése a Krím félsziget annektálása kapcsán [The Issue of Tourism and Security after the Annexation of the Crimean Peninsula]. In: Kiglics, N. (ed.): II. Turizmus és Biztonság Nemzetközi Tudományos Konferencia. Tanulmánykötet [II. Tourism and Security International Scientific Conference. Symposium.]. p. 140-149, Pannon Egyetem Nagykanizsai Kampusz.

Harb, A. (2016). Impact of War and Terrorism on Tourism and Hospitality Sector in Lebanon, Annual of Sofia University "St. Kliment Ohridski" Faculty of Geology and Geography, Book 2 - GEOGRAPHY, Volume 109.

Hungarian Consular Services (2019). https://konzuliszolgalat.kormany.hu/europa-utazasi-tanacsok?ukrajna, accessed 03.10.2019.

IMF (International Monetary Fund) (2019). World Economic Outlook Database, April 2019

Karácsonyi, D., Kocsis, K., Kovály, K., Molnár, J. \& Póti, L. (2014). East-West dichotomy and political conflict in Ukraine - Was Huntington right? Hungarian Geographical Bulletin 63(2), 99-134.

Kolosinska, M., Petrashchak, O., Kolosinskyi, I., \& Katana, A. (2018). Tourism Sector in Transition Economy on Example Of Ukraine: Determinants of Competitiveness. GeoJournal of Tourism and Geosites, 21(1), 239-252.

Kővári, I. \& Zimányi, K. (2011). Safety and security in the age of global tourism: The changing role and conception of Safety and Security in Tourism. APSTRACT - Applied Studies in Agribusiness and Commerce 5(3-4), 59-61, Agroinform Publishing House, Budapest.

Magyar Turisztikai Ügynökség [Hungarian Tourism Agency] (2016). A nemzetközi turistaérkezések száma megközelítette az egymilliárdot 2016 elsö kilenc hónapjában [The Number of International Tourist Arrivals Came Close to one Billion in the First Nine Months of 2016 ]. Budapest, p. 1-5. https://mtu.gov.hu/documents/prod/UNWTO_Turizmus_Barometer_2016_11.pdf, accessed 11.01.2020. 
Maslow, A. H. (1943). A Theory of Human Motivation. Psychological Review, 50, 370-396.

Michalkó, G. (2004). A határ menti büncselekmények turizmusföldrajzi aspektusai Magyarországon [Tourism Geography Aspects of Frontier Crimes in Hungary]. In: Hautzinger, Z. (ed.): Pécsi Határör Tudományos Közlemények III. [Pécs Frontier Guard Scientific Publications III.] Magyar Hadtudományi Társaság Határőr Szakosztály Pécsi Szakcsoportja, Pécs, 189-200.

Millennium Development Goals (2015). Ukraine: 2000-2015, National Report. Kyiv, p. 119. http://www.undp.org/content/dam/ukraine/docs/PR/2015 \%20MDGs\%20Ukraine\%20Report\%20engl.pdf, accessed 05.01.2019.

Mykhnenko, V. (2020). Causes and Consequences of the War in Eastern Ukraine: An Economic Geography Perspective. Europe-Asia Studies, 72(3), 528-560. DOI: $10.1080 / 09668136.2019 .1684447$.

Nezdoyminov, S. \& Shykina, O. (2016). Prospects of Development of Tourist Flow in Ukraine. Modern European Researches, 4, 82-90.

Pokharel, R., Poudel, J. \& Grala, R. (2018). Impact of economic factors and a political conflict on international tourism demand in Nepal: a vector error correction model. International Journal of Tourism Policy, 8(1), 18-41, Inderscience Enterprises Ltd.

Riashchenko, V., Zivitere, M., Kutyrieva, L. (2015). The problems of development of the Ukrainian tourist market and ways of their solutions. Information Technologies, Management and Society, 8(1), 21-26.

Sass, E. (2008). Kárpátalja Ukrajna turizmusában betöltött szerepének vizsgálata [Analysis of the Role of Transcarpathia in Ukraine’s Tourism.]. In Szónoky Ancsin, G. (ed.): Magyarok a Kárpát medencében. Tudományos nemzetközi konferencia [Hungarians in the Carpathian Basin. International Scientific Conference], CD-Rom, 465-476, Szeged.

Sass, E. (2017). A Study on Rural Tourism as a Rural Development Breaking Point in the Hungarian Minority Inhabited Areas in Slovakia and Ukraine. Szalók, Cs. (ed.): Változások és kihívások a turizmusban, Tanulmánykötet, 167-181, Budapesti Gazdasági Egyetem, Budapest.

Smoor, L. (2017). Understanding the Narratives Explaining the Ukrainian Crisis: Identity Divisions and Complex Diversity in Ukraine. Acta Univ. Sapientiae, European and Regional Studies, 11, 63-96.

Tátrai, P., Erőss, Á. \& Kovály, K. (2016). Migráció és versengő nemzetpolitikák Kárpátalján az Euromajdan után [Migration and Competing National Policies in Transcarpathia after Euromaidan]. REGIO 24(3), 82-110

Tátrai, P., Molnár, J., Molnár, D.I., Kovály, K., Erőss, Á., Ferenc, V., \& Rákóczi, K. (2018). A migrációs folyamatok hatása a kárpátaljai magyarok számának alakulására (The impact of recent migration flows on the number of Hungarians in Transcarpathia, Ukraine). Metszetek, 7(1), 5-29.

Varga H. \& Bagdi R. (2011). A terrorizmus hatása a nemzetközi idegenforgalomra [The effects of terrorism on international tourism]. ACTA CAROLUS ROBERTUS, 1(2), 175-186.

*** AASISTS (Support to the Implementation of the Association Agreement and of the National Strategy in the Transport Sector of Ukraine) (2018). PreFeasibility Study for the Bila Tserkva Airport in Ukraine - Final Report-18/10/2018, Kyiv, p. 182.

*** State Statistics Service of Ukraine (Державна служба статистики України) (2014). Туристична діяльність в Україні у 2013 роиі, Статистичний бюлетень [Tourist Activity in Ukraine in 2013, Statistical publication]. Київ.

*** State Statistics Service of Ukraine (Державна служба статистики України) (2018a). Туристична діяльність в Украӥні у 2017 році, Статистичний збірник [Tourist Activity in Ukraine in 2017, Statistical publication]. Київ.

*** State Statistics Service of Ukraine (Державна служба статистики України) (2018b). Колективні засоби розміщування в Украӥні у 2017 році, Статистичний збірник [Collective Accommodation Facilities in Ukraine in 2017, Statistical publication]. Київ.

*** State Statistics Service of Ukraine (Державна служба статистики України) (2019a). Regions of Ukraine 2019 Part I, Statistical publication, Kyiv, p. 309.

*** State Statistics Service of Ukraine (Державна служба статистики України) (2019b). Транспорт і зв'язок Украӥни 2018. Статистичний збірник [Ukraine's Transport and Communications in 2018. Statistical publication]. Київ, p. 152.

*** Statista (2020) https://www.statista.com/statistics/296140/ukraine-gross-domestic-product/, accessed 07.04.2020.

*** The Continuous Restriction of Language Rights In Ukraine (2019), Berehovo, p. 48, http://hodinkaintezet.uz. ua/wp-content/ uploads/2020/01/WrittenComments-Charter_2019.pdf?fbclid=IwAR0bmMCF ccdOsov28QpbNJPiqzvtXw83a_3WXt20qLmXoXMAXstu5M4TCIs, accessed 13.04.2019.

*** UNWTO (World Tourism Organization) (2007). World Tourism Barometer. Commited to Tourism, Travel and the Millennium Development Goals, Volum 5 No. 2 June 2007., p. 1-13.

*** UNWTO (World Tourism Organization) (2015). World Tourism Barometer, Volume 13, April 2015, p. 80

*** UNWTO (World Tourism Organization) (2017). UNWTO Tourism Highlights, 2017 Edition, UNWTO, Madrid, p. 15.

*** UNWTO (World Tourism Organization) (2018a). UNWTO Tourism Highlights, 2018 Edition, UNWTO, Madrid, p. 19

*** UNWTO (World Tourism Organization) (2018b). World Tourism Barometer, Volume 16, Issue 3, June 2018, p. 40.

*** UNWTO (World Tourism Organization) (2020). World Tourism Barometer, Volume 18, Issue 1, January 2020 , p. 47.

*** WTTC (World Travel \& Tourism Council) (2014). Travel \& Tourism Economic Impact 2014 Ukraine. London, p. 18

*** WTTC (World Travel \& Tourism Council) (2018). Travel \& Tourism Economic Impact 2018 Ukraine. March 2018, London, p. 18.

www.ukrstat.gov.ua - State Statistics Service of Ukraine documents publishing, accessed 09.01.2020. 